\title{
New records of snipe eels (Anguilliformes: Nemichthyidae) from the Pacific coast of lower Central America
}

\author{
Óscar Isaac Cruz-Mena' and Arturo Angulo 2,3,4*
}

\begin{abstract}
Background: New records of occurrence of two snipe eels (Avocettina bowersii and Nemichthys scolopaceus), poorly known for the Pacific coast of Costa Rica and Panama are herein reported.

Results: Specimens, 45 in total (28 and 17, respectively), were collected between 1972 and 1973 at depths between 295 and $1000 \mathrm{~m}$. Descriptions based on specimens as well as comparative morphometric and distributional information by species are herein presented and discussed. A key to the identification of the eastern Pacific species of the family also is presented.

Conclusion: These findings increase the knowledge on the Central American marine ichthyofauna and provide evidence of a broader distributional pattern for these species in the eastern Pacific region.
\end{abstract}

Keywords: Avocettina bowersii, Nemichthys scolopaceus, Eastern Pacific, Costa Rica, Panama, Deep-waters

\section{Background}

The Nemichthyidae represent a small group of highly modified pelagic fishes distributed in all tropical and temperate seas at depths down to $4000 \mathrm{~m}$ (Garman 1899; Nelson 2006; Fishbase 2015). Members of the family, commonly known as snipe eels, are characterized by having very elongate scaleless bodies, non-occlusible and beak-like jaws (except in fully mature males), pectoral fins present, dorsal and anal fins confluent with caudal fin, and 170 to over 750 vertebrae, among other distinctive characters (Nelson 2006; Nielsen \& Smith 1978).

Currently, three genera (Avocettina Jordan \& Davis, 1891; Labichthys Gill \& Ryder, 1883; and Nemichthys Richardson, 1848) and nine species of snipe eels are recognized as valid (Catalog of Fishes, 2015). The genus Avocettina with four species [A. acuticeps (Regan, 1916); A. bowersii (Garman, 1899); A. infans (Günther, 1878); and A. paucipora Nielsen \& Smith, 1978] is the most diverse;

\footnotetext{
* Correspondence: arturo.angulosibaja@ucr.ac.cr

${ }^{2}$ Museo de Zoología, Universidad de Costa Rica, 11501-2060 San Pedro de Montes de Oca, San José, Costa Rica

${ }^{3}$ Centro de Investigación en Ciencias del Mar y Limnología (CIMAR),

Universidad de Costa Rica, 11501-2060 San Pedro de Montes de Oca, San

José, Costa Rica

Full list of author information is available at the end of the article
}

whereas Nemichthys and Labichthys are represented by three and two species respectively $[N$. scolopaceus Richardson, 1848; N. curvirostris (Strömman, 1896); N. larseni Nielsen \& Smith, 1978; L. carinatus Gill \& Ryder, 1883; and L. yanoi (Mead \& Rubinoff, 1966)].

In the eastern Pacific Ocean five species of snipe eels have been recorded (A. bowersii; A. infans; $N$. curvirostris; $N$. larseni; and N. scolopaceus) (Garman 1899; Fishbase 2015); Nielsen \& Smith 1978; Pequeño 1989; Charter 1996; Catalog of Fishes 2015). Two species are restricted to the central and eastern Pacific (A. bowersii, from $58^{\circ} \mathrm{N}$ to about $30^{\circ} \mathrm{S}$; and $N$. larseni, from $47^{\circ}$ to $17^{\circ} \mathrm{N}$ ), while the other three (A. infans; N. curvirostris; and N. scolopaceus) are circumglobal (Fishbase 2015; Smith \& Nielsen 1989; Charter 1996).

To the authors' best knowledge, since Garman (1899) and Nielsen \& Smith's (1978) papers, which two species (A. bowersii and $N$. fronto Garman, 1899, now synonym of N. scolopaceus (Catalog of Fishes 2015; Smith \& Nielsen 1989), in Garman (1899); and A. bowersii and N. scolopaceus in Nielsen \& Smith (1978)) were listed from the Gulf of Panama and contiguous waters, there are no recent published records of snipe eels from the Pacific coast of Lower Central America (Costa Rica and Panama). Notably, to date, none of these species have been formally listed 
among the Costa Rican Pacific ichthyofauna (Bussing \& López 1994; Bussing \& López 2009; Bussing \& López 2011).

Between 1972 and 1973, during the field campaigns of the research vessels (R/V) Searcher and Velero IV (Cortés 2009), several specimens identified as "Nemichthyidae" were captured from the Pacific coasts of Costa Rica and Panama (between $9^{\circ} 30^{\prime}$ and $4^{\circ} 34^{\prime} \mathrm{N}$ ). This material, deposited at the fish collection of the Museo de Zoología of the Universidad de Costa Rica (UCR), was recently revised and two species were identified: A. bowersii and $N$. scolopaceus. In this contribution, these new records are formally reported; comparative morphometric data and distributional information are proportioned and discussed. In addition, a key to the identification of the eastern Pacific species of the family is presented.

\section{Results and discussion Systematics}

Genus Avocettina Jordan \& Davis, 1891

Avocettina bowersii (Garman, 1899)

(Table 1, Figs. 1a-b, and 2a-b)

\section{Material examined}

Twenty-eight specimens, 197-628 mm total length (TL): UCR 2676-002, $n=1,402 \mathrm{~mm}$ TL, near Isla del Caño, Costa Rica, $8^{\circ} 20^{\prime} 5^{\prime \prime} \mathrm{N}, 8^{\circ} 16^{\prime} 39^{\prime \prime} \mathrm{W}, 295-350$ m, 20 July 2004; UCR Searcher 493, $n=3$, 241-433 mm TL, $41 \mathrm{~km}$ SW Isla del Caño, Costa Rica, $8^{\circ} 17^{\prime} 4^{\prime \prime} \mathrm{N}, 84^{\circ} 7^{\prime} 48^{\prime \prime} \mathrm{W}$, 700 m, 22 March 1972, W.B. Bussing, M.M. Murillo et al.; UCR Searcher 494, $n=3,328-473 \mathrm{~mm}$ TL, $42 \mathrm{~km}$ SW Isla del Caño, Costa Rica, $8^{\circ} 18^{\prime} 0^{\prime \prime} \mathrm{N}, 84^{\circ} 6^{\prime} 44^{\prime \prime} \mathrm{W}$, 400 m, 22 March 1972, W.B. Bussing, M.M. Murillo et al.; UCR Searcher 504, $n=1,443 \mathrm{~mm}$ TL, SW of Gulf of Nicoya, Costa Rica, $8^{\circ} 29^{\prime} 24^{\prime \prime} \mathrm{N}, 8^{\circ} 11^{\prime} 23^{\prime \prime} \mathrm{W}, 830 \mathrm{~m}$, 7 March 1972, W.B. Bussing, M.M. Murillo et al.; UCR Velero-IV 19060, $n=1,345 \mathrm{~mm}$ TL, 30.0 miles, $195^{\circ} \mathrm{T}$ from Punta Burica, Costa Rica, $7^{\circ} 17^{\prime} 26^{\prime \prime} \mathrm{N}, 83^{\circ} 1^{\prime} 48^{\prime \prime} \mathrm{W}$,
400 m, 14 June 1973, R/V Velero IV; UCR Velero-IV 19070, $n=2$, 321-354 mm TL, Eastern Tropical Pacific, off Panama, Panama, $7^{\circ} 12^{\prime} 35^{\prime \prime} \mathrm{N}, 83^{\circ} 2^{\prime} 59^{\prime \prime} \mathrm{W}, 300 \mathrm{~m}$, 14 June 1973, R/V Velero IV; UCR Velero-IV 19072, $n=3,417-485 \mathrm{~mm}$ TL, Eastern Tropical Pacific, off Panama, Panama, $7^{\circ} 10^{\prime} 12^{\prime \prime N}, 83^{\circ} 4^{\prime} 12^{\prime \prime W}, 500$ m, 15 June 1973, R/V Velero IV; UCR Velero-IV 19073, $n=2$, 347-407 mm TL, Eastern Tropical Pacific, off Panama, Panama, $7^{\circ} 7^{\prime} 20^{\prime \prime} \mathrm{N}, 83^{\circ} 4^{\prime} 22^{\prime \prime} \mathrm{W}, 1000$ m, 15 June 1973, R/V Velero IV; Velero-IV 19076, $n=1,628 \mathrm{~mm}$ TL, Eastern Tropical Pacific, off Panama, Panama, 6 $31^{\prime} 56^{\prime \prime}$ N, 82 33'36"W, 500 m, 15 June 1973, R/V Velero IV; UCR UCR Velero-IV 19077, $n=2,298-446 \mathrm{~mm}$ TL, Eastern Tropical Pacific, off Panama, Panama, 6 $29^{\prime} 32^{\prime \prime}$ N, 82³3'42"W, 600 m, 15 June 1973, R/V Velero IV; UCR Velero-IV 19078, $n=3,302-476 \mathrm{~mm}$ TL, Eastern Tropical Pacific, off Panama, Panama, 6 $25^{\prime} 56^{\prime \prime} \mathrm{N}, 82^{\circ}$ 33'36"W, 800 m, 15 June 1973, R/V Velero IV; UCR Velero-IV 19088, $n=1$, $384 \mathrm{~mm}$ TL, Eastern Tropical Pacific, off Panama, Panama, $5^{\circ} 22^{\prime} 12^{\prime \prime} \mathrm{N}, 82^{\circ} 21^{\prime} 13^{\prime \prime} \mathrm{W}$, 500 m, 17 June 1973, R/V Velero IV; UCR Velero-IV 19090, $n=1,207 \mathrm{~mm}$ TL, Out of radar contact with land, $5^{\circ} 17^{\prime} 34^{\prime \prime} \mathrm{N}, 82^{\circ} 19^{\prime} 48^{\prime \prime} \mathrm{W}, 800 \mathrm{~m}, 17$ June 1973, R/ V Velero IV; UCR Velero-IV 19121, $n=2,361-452 \mathrm{~mm}$ $\mathrm{TL}$, Out of radar contact with land, Panama, $5^{\circ} 0^{\prime} 0^{\prime \prime} \mathrm{N}$, $82^{\circ} 17^{\prime} 59^{\prime \prime} \mathrm{W}, 500 \mathrm{~m}, 21$ June 1973, R/V Velero IV; UCR Velero-IV 19125, $n=1,197 \mathrm{~mm}$ TL, Out of radar contact with land, Panama, $5^{\circ} 16^{\prime} 48^{\prime \prime} \mathrm{N}, 82^{\circ} 5^{\prime} 59^{\prime \prime} \mathrm{W}$, 800 m, 21 June 1973, R/V Velero IV; UCR Velero-IV 19126, $n=1,344 \mathrm{~mm}$ TL, Out of radar contact with land, Panama, $5^{\circ} 19^{\prime} 12^{\prime \prime} \mathrm{N}, 82^{\circ} 1^{\prime} 48^{\prime \prime} \mathrm{W}, 1000 \mathrm{~m}, 21$ June 1973, R/V Velero IV.

\section{Description}

Morphometric measurements are presented in Table 1. Body long and slightly compressed. Mouth extremely long and pointed beak-like (except in a fully mature male). Maxilla with a small knob at the tip. Upper jaw

Table 1 Morphometric data of Avocettina bowersii from Costa Rica and Panama

\begin{tabular}{lll}
\hline Measurements & Females and immature males $(n=27)$ & Mature male $(n=1)$ \\
\hline MBD/SL (\%) & $1.68-3.04$ & 2.52 \\
HL/SL (\%) & $7.76-12.89$ & 6.98 \\
Sn-L/HL (\%) & $56.22-76.51$ & 22.22 \\
Sn-D/SL (\%) & $9.17-15.31$ & 8.03 \\
Sn-Pec/SL (\%) & $8.00-13.28$ & 7.75 \\
Sn-A/SL (\%) & $12.20-28.94$ & 17.36 \\
ID/HL (\%) & $2.24-5.48$ & 8.33 \\
ED/HL (\%) & $3.97-10.61$ & 13.09 \\
SL (mm) & $197-628$ & 361
\end{tabular}

Acronyms are as follow: MBD maximum body depth, $H L$ head length, $S n-L$ snout length, $S n-D$ snout to first dorsal fin length, $S n-p e c$ snout to pectoral fin length, $S n-A$ snout to anal fin length, ID interorbital distance, $E D$ eye diameter, $S L$ standart length 

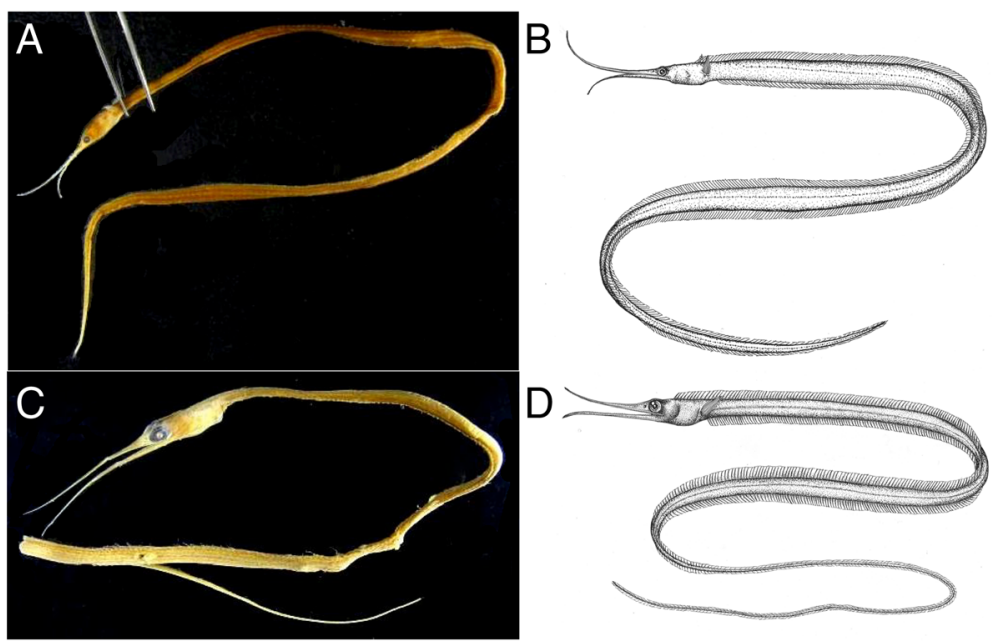

Fig. 1 a-b: Avocettina bowersii; a Preserved specimen (UCR 2676-002, 315 mm TL); b Drawing (UCR Velero-IV 19076, 628 mm TL). c-d Nemichthys scolopaceus; c Preserved specimen (UCR 0425-007, $397 \mathrm{~mm} \mathrm{TL);} \mathrm{d} \mathrm{Drawing} \mathrm{(UCR} \mathrm{Velero-IV} \mathrm{19122,} 836 \mathrm{~mm}$ TL)

longer than lower. Teeth numerous, small, close-set, recurved, distributed in diagonal rows. Eye small to medium sized, its diameter usually less $\tan 50 \%$ of head depth. Supraorbital pores 5-6, suborbital pores 5-7, postorbital pores $2-4$, preopercular pores 2. Posterior part of head, from eye to gill opening, usually narrower than rest of body; maximum body depth towards their posterior half. Lateral-line pores arranged in a single row. Pectoral fin-rays 15-17. Dorsal fin long, with welldeveloped spine-like rays, originating above (male) or behind (females and inmature males) pectoral fins. Anus located far forward, behind pectoral fins. Anal fin higher
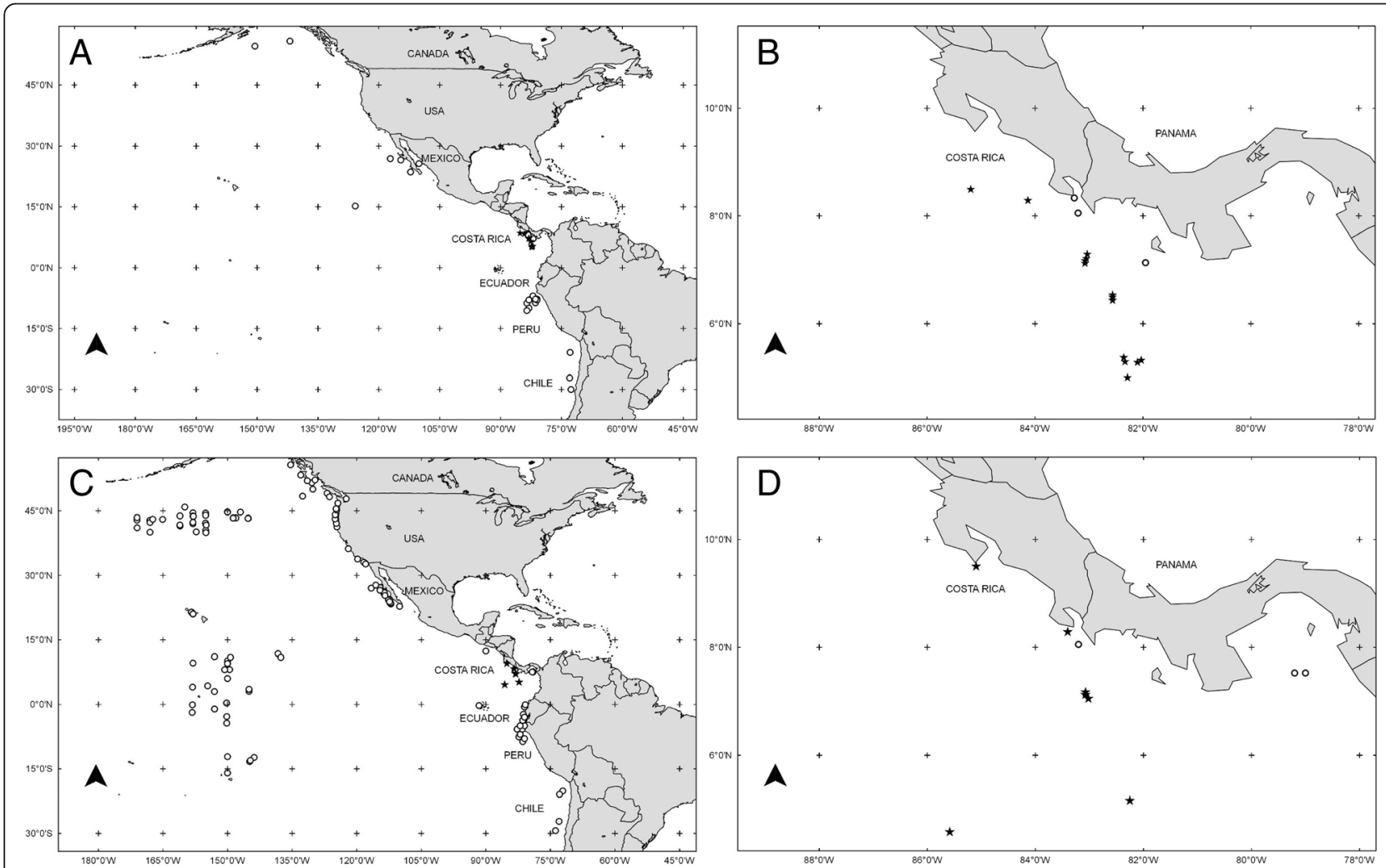

Fig. 2 Records of Avocettina bowersii (a-b) and Nemichthys scolopaceus (c-d) in the Eastern Pacific Ocean; a and c Whole area; b and $\mathbf{d}$ Lower Central America. Stars = present records; circles $=$ previous literature and museum records 
than dorsal fin. Caudal fin not ending in a long filament. Larger specimens tan to dark brown overlain with fine dark speckling; smaller specimens brownish-grey.

The data from the specimens herein described are in agreement with the size, body proportions and counts reported by other authors (Garman 1899; Nielsen \& Smith 1978) who systematically described this species.

\section{Remarks}

Avocettina bowersii is an oceanic species, which has been collected from the surface to depths up to $4000 \mathrm{~m}$ (Garman 1899; Wheeler 1969). It is found in the eastern Pacific Ocean from California, United States of America (USA), to central Chile (Catalog of Fishes 2015; Pequeño 1989; Charter 1996; McCosker 2009) (Fig. 2a and b). The present report constitutes, on the basis of Nielsen \& Smith (1978), the second documented record of the species in the Pacific coast of Costa Rica, and, after Garman (1899) and Nielsen \& Smith (1978) papers, the third documented record of the species in the Pacific coast of Panama.

\section{Systematics}

Genus Nemichthys Richardson, 1848

Nemichthys scolopaceus Richardson, 1848

(Table 2, Figs. 1c-d, and 2c-d)

\section{Material examined}

Seventeen specimens, 192-893 mm TL: UCR 0425-007, $n=1,397 \mathrm{~mm} \mathrm{TL}$, Between Cabo Blanco and Punta Herradura, Costa Rica, 18 May 1970, M. Gauthier; UCR 2290-005, $n=1,893 \mathrm{~mm}$ TL, In front of Cabo Blanco, Costa Rica, 9 $30^{\prime} 0^{\prime \prime} \mathrm{N}, 8^{\circ} 5^{\prime} 39^{\prime \prime} \mathrm{W}$, September 1992, W. Valdelomar; UCR Searcher 501, $n=2,457-762 \mathrm{~mm}$ TL, $20 \mathrm{Km} \mathrm{S}$ península de Osa, Costa Rica $\left(8^{\circ} 16^{\prime} 59^{\prime \prime} \mathrm{N}, 83^{\circ}\right.$ 23'59" W), 950 m, 21 March 1972, W.B. Bussing, M.M. Murillo et al.; UCR Velero-IV 19053, $n=1,192 \mathrm{~mm}$ TL, 31.3 miles, $178^{\circ} \mathrm{T}$ from Isla del Coco, Costa Rica, $4^{\circ} 34^{\prime}$
48"N, 85³4'58"W, 500 m, 5 June 1973, R/V Velero IV; UCR Velero-IV 19072, $n=3$, 295-606 mm TL, Eastern Tropical Pacific, off Panama, Panama, $7^{\circ} 10^{\prime} 12^{\prime \prime} \mathrm{N}, 83^{\circ} 4^{\prime}$ 12"W, 500 m, 15 June 1973, R/V Velero IV; UCR Velero-IV 19073, $n=2$, 194-240 mm TL, Eastern Tropical Pacific, off Panama, Panama, $7^{\circ} 7^{\prime} 20^{\prime \prime} \mathrm{N}, 8^{\circ} 4^{\prime} 22^{\prime \prime W}$, 1000 m, 15 June 1973, R/V Velero IV; UCR Velero-IV 19074, $n=3$, 192-378 mm TL, Eastern Tropical Pacific, off Panama, Panama, $7^{\circ} 2^{\prime} 59^{\prime \prime} \mathrm{N}, 83^{\circ} 1^{\prime} 12^{\prime \prime} \mathrm{W}, 300 \mathrm{~m}, 15$ June 1973, R/V Velero IV; UCR Velero-IV 19122, $n=3$, 382-836 mm TL, Out of radar contact with land, Panama, $5^{\circ} 9^{\prime} 36^{\prime \prime} \mathrm{N}, 82^{\circ} 15^{\prime} 0^{\prime \prime} \mathrm{W}, 750 \mathrm{~m}, 21$ June 1973, R/ V Velero IV; UCR 2676-002, $n=1,517 \mathrm{~mm}$ TL, near Isla del Caño, Costa Rica, $8^{\circ} 20^{\prime} 5^{\prime \prime} \mathrm{N}, 83^{\circ} 16^{\prime} 39^{\prime \prime} \mathrm{W}, 295-350$ m, 20 July 2004.

\section{Description}

Morphometric measurements are presented in Table 2. Body long and slightly compressed. Mouth extremely long and pointed beak-like (except in a fully mature male). Maxilla without a small knob at the tip. Upper jaw longer than lower. Teeth numerous, small, close-set, slightly recurved backwards, distributed in diagonal rows. Eye relatively large, its diameter about $50 \%$ of head depth. Supraorbital pores 9-11, suborbital pores 12-15, postorbital pores 7-10, preopercular pores 5-6. Posterior part of head, from eye to gill opening, usually deeper than rest of body. Lateral-line pores arranged in three longitudinal rows, the upper and lower forming a square with the median between and slightly below the midline. Pectoral fin-rays 10-13. Dorsal fin long, with well-developed spine-like rays, tapering toward the tail, originating about $66 \%$ the distance between posterior edge of eye and pectoral fin. Anus located beneath pectoral fins base. Anal fin higher than dorsal fin. Caudal fin ending in a long filament. Larger specimens dark brown-grey with light grey belly; smaller specimens brownish-grey with light beige belly.

Table 2 Morphometric data of Nemichthys scolopaceus from Lower Central America (This study) and comparative data

\begin{tabular}{|c|c|c|c|c|c|}
\hline \multirow[t]{2}{*}{ Measurements } & \multirow{2}{*}{$\begin{array}{l}\text { Puget Sound, USA } \\
\text { (Jordan \& Gilbert 1881) }\end{array}$} & \multirow{2}{*}{$\begin{array}{l}\text { Strait of Messina, Italy } \\
\text { (Genovese 1954) }\end{array}$} & \multirow{2}{*}{$\begin{array}{l}\text { Aegen Sea, Turkey } \\
\text { (Bilecenoglu et al. 2006) }\end{array}$} & \multicolumn{2}{|l|}{ Lower Central America } \\
\hline & & & & Females and immature males $(n=16)$ & Mature male $(n=1)$ \\
\hline$\overline{M B D} / S L(\%)$ & 1.54 & 0.69 & $0.98-1.68$ & $0.77-2.18$ & 2.03 \\
\hline HL/SL (\%) & 9.81 & 6.79 & $9.11-9.15$ & $5.55-14.58$ & 7.32 \\
\hline Sn-L/HL (\%) & 80.95 & 68.11 & $64.64-66.67$ & $50.42-70.31$ & 19.16 \\
\hline Sn-D/SL $(\%$ & - & 6.60 & 3.27 & $6.10-12.73$ & 4.64 \\
\hline Sn-Pec/SL (\%) & - & 7.19 & 4.10 & $7.96-15.36$ & 8.39 \\
\hline Sn-A/SL (\%) & - & 7.98 & 4.97 & $8.17-16.04$ & 9.15 \\
\hline ID/HL (\%) & - & 6.52 & 4.53 & $2.40-5.47$ & 10.31 \\
\hline $\mathrm{ED} / \mathrm{HL}(\%)$ & 8.57 & 7.24 & $8.27-10.83$ & $4.92-8.60$ & 15.72 \\
\hline $\mathrm{SL}(\mathrm{mm})$ & 543.5 & 1015 & $820.5-974.0$ & 192-893 & 556 \\
\hline
\end{tabular}

Acronyms are listed in Table 1. Unavailable measurements are represented with an en-dash (-) 
The data from the specimens herein described are in agreement with the size, body proportions and counts reported by other authors (Garman 1899; Nielsen \& Smith 1978; Jordan \& Gilbert 1881; Genovese 1954; Bilecenoglu et al. 2006; Filiz et al. 2007) who systematically described this species.

\section{Remarks}

Nemichthys scolopaceus is an oceanic species, which has been collected from the surface down to depths of $2500 \mathrm{~m}$ (Fishbase 2015); Charter 1996). It is found in the eastern Pacific Ocean from Alaska, United States of America (USA), to Central Chile (Fishbase 2015); Nielsen \& Smith 1978; Pequeño 1989; McCosker 2009) (Fig. 2c and d). The present record constitutes, on the basis of Nielsen \& Smith (1978) and Bussing \& López (1994; 2009; 2011), the first documented record of the species in the Pacific coast of Costa Rica, and, after Garman (1899) and Nielsen \& Smith (1978), the third documented record of the species in the Pacific coast of Panama.

\section{Key to eastern Pacific species of the family Nemichthyidae}

The following key is based on our research and data available in the literature (Garman 1899; Nielsen \& Smith 1978; Charter 1996; McCosker 2009)

1a Lateral-line pores arranged in a single row; anus posterior to pectoral fins; precaudal vertebrae 59-72; caudal region attenuate (see Fig. 1a-b) ... 2

1b Lateral-line pores arranged in three longitudinal rows, with five pores per segment forming a square or a rectangle; anus below pectoral fins; precaudal vertebrae 79-105; caudal region filiform (see Fig. 1c-d) ... 3

2a Eye small to medium sized, its diameter 18-29\%, usually around $22 \%$, of postorbital length; predorsal pores $6-11$, usually 9 ; predorsal length $32-48 \%$, usually around $38 \%$, of preanal length; precaudal vertebrae usually 59-66 (from California, USA, to Central Chile)... Avocettina bowersii

2b Eye medium sized to large, its diameter 24-47\%, usually around $35 \%$, of postorbital length; predorsal pores $5-8$, usually 6 ; predorsal length $21-39 \%$, usually around $30 \%$, of preanal length; precaudal vertebrae usually 69-72 (from Queen Charlotte Islands and British Columbia, Canada to central Mexico, including the Gulf of California)... Avocettina infans

3a Postorbital pores 12-23; preopercular pores 8-17; lateral line pores form a rectangle shorter than high (from Oregon, USA, to central Mexico, including the Gulf of California)... Nemichthys larseni

3b Postorbital pores 3-14; preopercular pores 2-8; lateral line pores form a square or a rectangle longer than high ... 4 4a Body pale with large melanophores scattered along the ventral surface, usually concentrated around stomach; dorsal and anal fins edged in black posteriorly on the caudal filament; subcutaneous dark bars between vertebrae presents (from Central Chile, rare)... Nemichthys curvirostris

4b Body uniformly dark or countershaded, more or less pigmented; dorsal and anal fins not edged in black posteriorly on the caudal filament; subcutaneous dark bars between vertebrae absents (from Alaska, USA, to Central Chile)... Nemichthys scolopaceus

\section{Conclusions}

Avocettina bowersii and Nemichthys scolopaceus are herein formally reported from the Pacific coast of Costa Rica and Panama. These findings increase the knowledge on the Central American marine ichthyofauna and provide evidence of a broader distributional pattern for these species in the eastern Pacific region.

\section{Methods}

Counts and measurements (Tables 1 and 2) were taken on the left side of the specimens Genovese (1954) and Nielsen \& Smith (1978). Measurements were made using calipers to the nearest tenth millimeter $(\mathrm{mm})$ or measuring tape to the nearest $\mathrm{mm}$. Comparative information was obtained from the literature (Nielsen \& Smith 1978; Smith \& Nielsen 1989; Jordan \& Gilbert 1881; Genovese 1954; Bilecenoglu et al. 2006; Filiz et al. 2007). Maps were made using QUANTUM GIS 2.0. Distributional data information was obtained from the literature (Garman 1899; Nielsen \& Smith 1978; Pequeño 1989; Bilecenoglu et al. 2006; Chirichigno \& Vélez 1998) and from the Ocean Biogeographic Information System (OBIS) online database (Ocean Biogeographic Information System 2015).

\section{Abbreviations}

CIMAR: Centro de Investigación en Ciencias del Mar y Limnología; ED: eye diameter; HL: head length; ID: interorbital distance; MBD: maximum body depth; RN: research vessel; SL: standart length; Sn-A: snout to anal fin length; Sn-D: snout to first dorsal fin length; Sn-L: snout length; Sn-pec: snout to pectoral fin length; TL: total length; UCR: Universidad de Costa Rica; USA: United States of America.

\section{Competing interests}

The authors declare that they have no competing interests.

\section{Authors' contributions}

OICM carried out the measurements of the specimens and drafted the manuscript. AA conceived of the study, and participated in its design and coordination and helped to draft the manuscript. Both authors read and approved the final manuscript.

\section{Authors' information}

OICM is a master student at the Universidad Nacional de Costa Rica, Heredia, Costa Rica. To complete their grade studies, he participated, in collaboration with the second author, in a short-term lab work at the UCR, which derived in this publication.

AA is a PhD student at the Universidade Estadual Paulista "Júlio de Mesquita Filho", São Paulo, Brazil and research associate at the Museo de Zoología and 
CIMAR, UCR, San José, Costa Rica. In his master thesis he studied the deepwater fish fauna of the Pacific coast of Costa Rica.

\section{Acknowledgements}

The authors are grateful to William A. Bussing (1933-2014), Myrna I. López, Ana Rosa Ramírez and the authorities of the Museo de Zoología, the Escuela de Biología, and the CIMAR of the UCR for the encouragement and facilities provided. David G. Smith kindly provided us PDF copies of their publications. Ryosuke Sahara photographed the specimens and Laura Achí made the illustrations. This research received no specific grant from any funding agency, commercial or not-for-profit sectors.

\section{Author details}

${ }^{1}$ Escuela de Ciencias Biológicas, Facultad de Ciencias Exactas y Naturales, Universidad Nacional, Heredia, Costa Rica. ${ }^{2}$ Museo de Zoología, Universidad de Costa Rica, 11501-2060 San Pedro de Montes de Oca, San José, Costa Rica. ${ }^{3}$ Centro de Investigación en Ciencias del Mar y Limnología (CIMAR), Universidad de Costa Rica, 11501-2060 San Pedro de Montes de Oca, San José, Costa Rica. ${ }^{4}$ Laboratório de Ictiologia, Departamento de Zoologia e Botânica, Universidade Estadual Paulista "Júlio de Mesquita Filho", Rua Cristóvão Colombo, 2265, 15054-000 São José do Rio Preto, São Paulo, Brazil.

Received: 27 January 2016 Accepted: 8 February 2016

Published online: 08 March 2016

\section{References}

Bilecenoglu M, Kaya M, Irmak E. First records of the slender snipe eel, Nemichthys scolopaceus (Nemichthyidae), and the robust cusk-eel, Benthocometes robustus (Ophidiidae), from the Aegean Sea. Acta Ichtyol Pisc. 2006;36:85-8.

Bussing WA, López MI. Peces demersales y pelagicos costeros del Pacífico de Centro América Meridional: guía ilustrada/Demersal and pelagic inshore fishes of the Pacific coast of lower Central America: an illustrated guide. 1st ed. San José: Editorial Universidad de Costa Rica; 1994

Bussing WA, López MI. Marine Fish. In: Wehrtmann IS, Cortés J, editors. Marine biodiversity of Costa Rica, Central America. Berlin: Springer Business Media; 2009. p. 453-8.

Bussing WA, López MI. Peces demersales y pelagicos costeros del Pacífico de Centro América Meridional: guía ilustrada/Demersal and pelagic inshore fishes of the Pacific coast of lower Central America: an illustrated guide. 2nd ed. San José: Editorial Universidad de Costa Rica; 2011.

Catalog of Fishes. Genera, Species, References. http://research.calacademy.org/ research/ichthyology/catalog/fishcatmain.asp (2015). Accessed 14 July 2015

Catalog of Fishes. Species by Family/Subfamily. http://researcharchive. calacademy.org/research/ichthyology/catalog/SpeciesByFamily.asp (2015). Accessed 14 July 2015.

Charter SR. Nemichthyidae: snipe eels. In: Moser HG, editor. The early stages of fishes in the California Current region. California: California Cooperative Oceanic Fisheries Investigations; 1996. p. 122-9.

Chirichigno FN, Vélez JD. Clave para identificar los peces marinos del Perú (Segunda edición, revisada y actualizada). Peru: Publicaciones de Instituto del Mar del Peru, Publicación especial; 1998.

Cortés J. A history of marine biodiversity scientific research in Costa Rica. In: Wehrtmann IS, Cortés J, editors. Marine biodiversity of Costa Rica, Central America. Berlin: Springer Business Media; 2009. p. 47-80.

Filiz H, Akçinar CS, Ulutürk E, Bayhan B, Taşkavak E, Sever MT, Bilge G, Irmak E. New records of Bregmaceros atlanticus (Bregmacerotidae), Echiodon dentatus (Carapidae), and Nemichthys scolopaceus (Nemichthyidae) from the Aegean Sea. Acta Ichtyol Pisc. 2007;37:107-12.

Fishbase. http://fishbase.org/(2015). Accessed 14 July 2015.

Garman S. Reports on an exploration off the west coasts of Mexico, Central and South America, and off the Galapagos Islands, in charge of Alexander Agassiz, by the U.S. Fish Commission Steamer "Albatross," during 1891, Lieut. Commander Z.L. Tanner, U.S.N., Commanding. XXVI. The Fishes. Mem Mus Comp Zool̈ Harv Coll. 1899;24:1-431.

Genovese S. Su una nuova cattura di Nemichthys scolopaceus Rich. nello Stretto di Messina. Ital J Zool. 1954;21:81-92.

Gill TN, Ryder JA. Diagnoses of new genera of nemichthyoid eels. Proc. U. S. Nat. Mus. 1883;6:260-262.

Günther A. Preliminary notices of deep-sea fishes collected during the voyage of H. M. S. "Challenger". Ann. Mag. Nat. Hist. 1878;2:17-251.
Jordan DS, Davis B.M. A preliminary review of the apodal fishes or eels inhabiting the waters of America and Europe. United States Commission of Fish and Fisheries, Report of the Commissioner 1891;16:581-677.

Jordan DS, Gilbert CH. Description of a new species of Nemichthys (Nemichthys avocetta), from Puget Sound. Proc U S Natl Mus. 1881;3:409-10.

Mead GW, Rubinoff I. Avocettinops yanoi, a new nemichthyid eel from the southern Indian Ocean. Breviora 1966;241:1-6.

McCosker JE. Nemichthyidae. In: Nakaya K, Yabe M, Imamura H, Romero MC, Yoshida M, editors. Deep-sea fishes of Peru. Tokyo: Japan Deep Sea Trawlers Association; 2009. p. 80-1.

Nelson JS. Fishes of the World. 4th ed. Hoboken: John Wiley and Sons; 2006.

Nielsen JG, Smith DG. The eel family Nemichthyidae (Pisces: Anguilliformes). Dana Report. 1978;88:1-71.

Ocean Biogeographic Information System. Intergovernmental Oceanographic Commission of UNESCO. http://www.iobis.org. Accessed 14 July 2015.

Pequeño G. Peces de Chile. Lista sistemática revisada y comentada. Rev Biol Mar. 1989;24:1-132.

Regan CT. Larval and postlarval fishes. British Antarctic ("Terra Nova" Expedition (1910-1913). Zoology 1916;4:125-156.

Smith DG, Nielsen JG. Family Nemichthyidae. In: Böhlke EB, editor. Orders Anguilliformes and Saccopharyngiformes. Fishes of the western North Atlantic. Yale: Sears Foundation of Marine Research; 1989. p. 441-59.

Strömman PH. Leptocephalids in the University Zoological Museum at Upsala. Upsala: Almqvist \& Wiksell; 1896.

Wheeler A. The Fishes of the British Isles and North-west Europe. London: Macmillan; 1969.

\section{Submit your next manuscript to BioMed Central and we will help you at every step:}

- We accept pre-submission inquiries

- Our selector tool helps you to find the most relevant journal

- We provide round the clock customer support

- Convenient online submission

- Thorough peer review

- Inclusion in PubMed and all major indexing services

- Maximum visibility for your research

Submit your manuscript at www.biomedcentral.com/submit
) Biomed Central 